\title{
The position of patients for safe central venous catheterization via the internal jugular vein: prospective observational study of critically ill patients
}

\author{
Young Soon Cho*, Jong Bin Lee \\ From 10th WINFOCUS World Congress on Ultrasound in Emergency and Critical Care \\ Kuala Lumpur, Malaysia. 16-19 November 2014
}

\section{Background}

Carotid artery injuries are common complications during catheterization of the internal jugular vein.

\section{Objective}

The purpose of this study is to determine the best position for the reduction of carotid artery injuries. Unlike a previous study, only critically ill patients who needed central venous catheterization in an emergency medical center were included.

\section{Patients and methods}

Eight positions were tested in each patient. The positions were classified by maneuver and ultrasound images of each position were stored. Two factors were determined at each position: "safety width" (the part of the internal jugular vein that did not overlap with the carotid artery) and "overlap width" (the part of the internal jugular vein that did overlap with the carotid artery).

\section{Results}

Compared with the neutral bed position, safety widths were significantly larger in the Trendelenburg position, and there were no statistical difference in overlap widths. Compared with the non-head rotation position, safety widths were smaller and overlap widths were significantly larger in the 45 head rotation positions. Safety widths did not statistically change safter adjustments for ultrasound probe level. However changing the ultrasound probe level from the base of Sedillot's triangle to thyroid cartilage

\footnotetext{
* Correspondence: emer0717@gmail.com

Department of Emergency Medicine, Soonchunhyaung University Bucheon Hosptial, Bucheon, Korea
}

Cite this article as: Cho and Lee: The position of patients for safe central venous catheterization via the internal jugular vein: prospective observational study of critically ill patients. Critical Ultrasound Journal 20157 (Suppl 1):A15.

Submit your manuscript to a SpringerOpen ${ }^{\odot}$ journal and benefit from:

- Convenient online submission

- Rigorous peer review

- Immediate publication on acceptance

- Open access: articles freely available online

- High visibility within the field

Retaining the copyright to your article

Submit your next manuscript at $>$ springeropen.com 